\title{
Viruses That Can Cure, When Antibiotics Fail...
}

\author{
Verbeken $\mathrm{G}^{1-3 *}$, Pirnay $\mathrm{JP}^{1}$, Lavigne $\mathrm{R}^{4}$, Ceulemans $\mathrm{C}^{3}$, De Vos $\mathrm{D}^{1}$ and Huys $\mathbf{I}^{2,5}$ \\ ${ }^{1}$ Laboratory for Molecular and Cellular Technology, Burn Wound Centre, Queen Astrid Military Hospital, Bruynstraat, Brussel, Belgium \\ ${ }^{2}$ Faculty of Pharmaceutical and Pharmacological Sciences, KU Leuven, Herestraat, Leuven, Belgium \\ ${ }^{3}$ Department of Behavioural Sciences, Royal Military Academy, Renaissancelaan, Brussel, Belgium \\ ${ }^{4}$ Laboratory of Gene Technology, KU Leuven, Leuven, Belgium \\ ${ }^{5}$ Centre for Intellectual Property Rights, KU Leuven, Minderbroedersstraat, Leuven, Belgium
}

\begin{abstract}
Resistance of bacteria to antibiotics just keeps growing. Industry's antibiotic pipeline is running dry. Before the pharmaceutical development of antibiotics, natural bacteriophages (=bacterial viruses) were commercialised and used to kill pathogenic bacteria. This therapeutic application of natural bacteriophages was called "bacteriophage therapy". Today, countries like Poland, Georgia and Russia are still practising bacteriophage therapy. The European Union and "modern" medicine as a whole needs an urgent return of bacteriophage therapy as part of its armamentarium to fight bacterial resistance to antibiotics. This paper reflects on the issue and proposes a European regulatory frame that could fit the re-introduction of bacteriophage therapy without losing sight of safety, quality and efficacy aspects.
\end{abstract}

Keywords: Antibiotic resistance; Bacteriophages; Bacteriophage therapy; Regulatory; Viruses

\section{Resistance of Bacteria to Antibiotics}

The treatment of infectious diseases with antibiotics is becoming increasingly challenging [1,2]. Antimicrobial resistance (AMR) is a serious threat to global public health. In Europe, 25,000 patients die annually from untreatable infections [3-5]. The situation may deteriorate further, as there are only a few drugs left to treat multidrugresistant bacterial strains and the first strains that are resistant to even these last-resort antibiotics have already emerged [6,7]. Moreover, there is a dearth of genuinely novel antibiotics in the development pipeline despite global efforts by health organisations and political initiatives, including the ' $10 \times 20$ ' initiative of the Infectious Diseases Society of America (IDSA), the 'New Drugs for Bad Bugs' initiative (NDBBI) and the US GAIN Act $[5,8-13]$. Various proposals have been made to address the problem using novel antimicrobials. One approach seems to be promising and sustainable at the long term and implementable in the near future. That approach is called "bacteriophage therapy", the use of bacteriophages (bacterial viruses) to kill bacteria. Indeed, the use of bacteriophages to kill specific bacterial pathogens without harming the majority of the commensal bacteria has received increasing attention during the past decade [2,14-37]. Since almost a century, bacteriophages, independently discovered by Twort in the UK and d'Herelle in France, have been put forward and are used as antibacterial agents [26]. The principle, set forward by d'Herelle, is using the bacterium's natural predator as weapon against a specific pathogenic bacterium. A single lytic bacteriophage can specifically recognize and bind its host, inject its genetic material and convert the bacterium into a virus producing machine. In a final step of their replication cycle, a large number of progeny bacteriophages are released by breaking down the cell wall, thus killing the host. In this manner, newly formed virus particles are ready for a next round of infection.

\section{Bacterial Resistance to Bacteriophages}

Bacteria can develop resistance to bacteriophages [21] through a variety of different mechanisms, including blocking bacteriophage adsorption, inhibiting the injection of bacteriophage genomes, restriction-modification systems, and abortive infection systems [3840]. In in vitro monoculture studies, bacteriophage resistance can evolve in time frames of hours to days depending on mutation and growth rates. Whether the evolution of bacteriophage resistance in vitro is relevant to in vivo conditions where bacteria may be replicating more slowly and challenged with a greater set of environmental conditions can be questioned [41]. Bacteriophage mutants more active against the bacteriophage-resistant bacteria can be selected from the environment. Therapeutic bacteriophage banks, as they exist in Georgia and Poland, contain many different natural therapeutic bacteriophages and are regularly updated [42]. In 2015, the first modern "Western" European natural therapeutic bacteriophage bank was opened at the German Leibniz Institute - Deutsche Sammlung von Microorganism und Zellkulturen GmbH (DSMZ). Bacteriophages deposited in this special collection of the DSMZ could be of therapeutic interest if further propagated and prepared as new stocks under appropriately controlled conditions prior to their therapeutic application [43]. Naturally evolved bacteriophages, isolated from the environment or the patient's bacteria, can be stored (for later use) in these banks. Patient-tailored bacteriophage preparations can also be developed [42].

\section{The Co-Evolutionary Concept Bacterium/Bacteriophage}

Bacteriophage therapy can be defined as the use of exclusively lytic bacterio-specific viruses as antibacterial agents. By setting up a screening system for the circulating noxious bacteria and their respective bacteriophages, it is possible to obtain the right bacteriophage against any emerging pathogen. Any sustainable bacteriophage therapy concept should, based on scientific grounds, fully acknowledge the potentialities of the co-evolutionary aspect of

*Corresponding author: Verbeken G, Laboratory for Molecular and Cellular Technology, Burn Wound Centre, Queen Astrid Military Hospital, Bruynstraat, Brussel, Belgium, Tel: + 322264 4856; E-mail: gilbert.verbeken@mil.be

Received December 03, 2015; Accepted December 15, 2015; Published December 22, 2015

Citation: Verbeken G, Pirnay JP, Lavigne R, Ceulemans C, De Vos D, et al. (2016) Viruses That Can Cure, When Antibiotics Fail... J Microb Biochem Technol 8: 021 024. doi:10.4172/1948-5948.1000257

Copyright: (c) 2016 Verbeken G, et al. This is an open-access article distributed under the terms of the Creative Commons Attribution License, which permits unrestricted use, distribution, and reproduction in any medium, provided the original author and source are credited. 
the couplet bacteriophage/bacterium in its ecological environment, in casu the human being. Bacteria will inevitably become resistant to bacteriophages, but due to the continuously ongoing "arms race" between the two protagonists, specific bacteriophages able to infect the formerly resistant bacterial strains will quickly emerge [44-49].

\section{European Human Medicinal Products Legislation}

For practitioners at hospitals seeking to use bacteriophages for treatment of antibiotic-resistant bacterial infections, Europe's current regulatory framework for human medicinal products hinders more than it facilitates [50]. Although many experts consider bacteriophage therapy to be a promising complementary (or alternative) treatment to antibiotic therapy, no bacteriophage-specific regulatory framework exists to date. Today, bacteriophage therapy is only approved in some former Soviet Republics like Russia and Georgia [21]. In Poland, a recent member of the European Union, bacteriophage therapy is considered an 'Experimental Treatment' covered by the Physician Practice Act (Polish Law Gazette $\mathrm{N}^{\circ} 28$ of 1997) and the Declaration of Helsinki, where other therapeutic options do not exist [2]. In France, therapeutic made-to-order bacteriophage preparations from the Pasteur Institutes (Paris and Lyon) were used until the beginning of the nineties. Historical clinical data on bacteriophage therapy (from Eastern Europe, particularly Poland, and the former Soviet Republics, particularly Georgia and Russia, as well as from today's 28 EU member states and the US) collected during the past decades are not taken into account by European regulators since these data were not collected in compliance with today's Western standards [51]. The current pharmaceutical economic model, implying costly and timeconsuming pathways for human medicinal product development and marketing, and requiring strong intellectual property protection, is not compatible with a (possible) smooth re-introduction of traditional sustainable bacteriophage therapy into the European Union. Another major obstacle for the clinical application of bacteriophages is a false perception of viruses as 'enemies of life' [52]. Bacteriophages are not straightforward inanimate and stable substances. They are evolvable and natural biological entities. Sustainable bacteriophage therapy legislative frameworks should fully acknowledge the potential of the co-evolutionary aspect of the bacteriophage/bacterium couplet. A specific European regulatory frame with realistic production and documentation requirements, which allows a timely (rapid) supply of safe, tailor-made, natural bacteriophages to patients, is a must [13]. Fundamental changes of mentality in the medical and pharmaceutical environment are essential for a successful re-introduction of bacteriophage therapy into modern Western medicine [53].

\section{Can We Adapt European Legislation to Fit Bacteriophage Therapy?}

A suitable European legislative environment for bacteriophage therapy should be developed in collaboration with the competent authorities and responsible political and economic actors. The setting up of credible scientific studies and credible clinical trials needs to be stimulated. Natural bacteriophages are, by definition, "products" in the pharmaco-legal jargon. They are natural, lifelike biological entities. Bacteriophages can be categorized at potentially two (new) classification places under Annex 1 Part III of Human Medicinal Products Directive 2001/83/EC [54]. A first possibility is the creation of a new and specific "Biological Medicinal Products" categorical ranking place under the name "Bacteriophage Medicinal Products" at the same rank level as "Plasma-Derived Medicinal Products" and "Vaccines". The second possibility can be the creation of a dedicated new category of the Part
III Particular Medicinal Products division. Both proposed new legal frame options are visualized in Table 1 and concern as "products" only the natural exclusively lytic natural bacteriophages.

Another option could be the creation of a new and dedicated Bacteriophage Therapy Directive, outside the existing Human Medicinal Products Directive 2001/83/EC. New legislative frames tailored to bacteriophage therapy should allow an adapted developmental time frame. The development of a "new" natural bacteriophage "product" can in practice happen in a matter of days to weeks [42], in contrast to the time frames applicable to the developing of classical chemical antibiotics. These new or adapted frameworks should also make the tailored use of bacteriophage therapy in hospitals or recognized bacteriophage therapy centres possible. In case the European Union would not actively support, in the near future, the re-introduction of tailored bacteriophage therapy into its Member States, national authorities could regulate bacteriophage therapy at their level. There is an urgent need for bacteriophage therapy centres in view of the increasing antibiotic resistances and its negative consequences. If in the actual pharmaco-economic environment the launch of hospitalbased (non-profit) bacteriophage therapy centres should be financially impossible, national governments should support those initiatives and eventually help to develop new pharmaco-economic models. Last but not least, it could be contended that the tailored production and the in-hospital use of a natural therapeutic bacteriophage does not constitute a market placement of this product and, by doing so, places this product and its use outside the scope of the European Medicinal Product Directive 2001/83/EC [55]. Also this argument motivates for the creation of a totally new and specific European Bacteriophage Therapy Directive.

\section{The Moral Issue}

The need to introduce an adequate regulatory framework for

\begin{tabular}{|c|c|}
\hline Part I & Standardized marketing authorisation dossier \\
\hline \multirow[t]{8}{*}{ Part II } & Specific marketing authorisation dossier \\
\hline & - Well-established medicinal use \\
\hline & - Essentially similar medicinal products \\
\hline & - Additional data required in specific situations \\
\hline & - $\quad$ Similar biological medicinal products \\
\hline & - $\quad$ Fixed combination medicinal products \\
\hline & - Documentation for applications in exceptional circumstances \\
\hline & - $\quad$ Mixed marketing authorisation applications \\
\hline \multirow[t]{12}{*}{ Part III } & Particular medicinal products \\
\hline & - Biological medicinal products \\
\hline & - $\quad$ Plasma-derived medicinal products \\
\hline & - $\quad$ Vaccines \\
\hline & - $\quad$ Bacteriophage medicinal products \\
\hline & - $\quad$ Radio-pharmaceuticals and precursors \\
\hline & - $\quad$ Radio-pharmaceuticals \\
\hline & - $\quad$ Radio-pharmaceutical precursors for radio-labelling purposes \\
\hline & - Homeopathic medicinal products \\
\hline & - Herbal medicinal products \\
\hline & - Orphan medicinal products \\
\hline & - Bacteriophage medicinal products \\
\hline \multirow[t]{3}{*}{ Part IV } & Advanced Therapy Medicinal Products \\
\hline & - Gene therapy medicinal products \\
\hline & - $\quad$ Somatic cell therapy medicinal products \\
\hline
\end{tabular}

Table 1: Annex 1 Part III of Human Medicinal Products Directive 2001/83/EC in which the bacteriophage therapy concept could be integrated or classified. 
bacteriophage therapy is of course much more than a purely legal issue. It is also and perhaps especially so a moral issue. Indeed, we should never forget that political and economic institutions do not exist for their own sake. They are not ends in themselves. Their core business is, or at least should be, the protection and promotion of human wellbeing. In that perspective, one cannot escape the conclusion that bacteriophage therapy must be taken seriously by all stakeholders. The pharmaceutical industry, the competent authorities, lawmakers, regulators, and politicians have the moral duty and the shared responsibility towards making bacteriophage therapy urgently available for all patients in need [56]. The pharmaceutical industry has a moral duty to invest in antibacterial therapies like bacteriophage therapy, in view of the social responsibility they need to take. Of equally crucial importance is the role of the competent public authorities to create the appropriate legislative framework to stimulate companies to invest in bacteriophage therapy. Political representatives and lawmakers have an inevitable, logical responsibility to support health care and welfare. The development and production of bacteriophage products in a classical pharmaceutical context (clinical trials, production requirements, marketing authorization procedures...) requires a great deal of time. Patients in need have no time. Therefore, lawmakers and regulators need to design appropriate solutions, on a short term, to buffer for the years needed for companies to develop bacteriophage-based medicinal products. Much more urgent and optimal, legislative solutions need to be created to allow hospitals to adopt patient-oriented and tailored bacteriophage therapy in a legal way for treating those patients that are waiting to be cured today.

\section{Environmental Risks}

Bacteriophages are the natural controllers of bacteria in the environment (rivers, soils, plants, animals...). Little is known about the ecological effects that (high concentrations) of bacteriophages in the environment might have on local natural microbial communities. A better and more fundamental understanding of the cost/benefits of resistance to bacteriophage predation and of synergistic effects among bacteriophages in controlling bacterial pathogens will allow for a more informed development and application of treatment, and ideally the prevention of widespread resistance [57-60]. Studying the environmental risk issue is very relevant in relation to the largescale use of bacteriophages as e.g. bio-pesticides in agriculture. The controlled, tailored, hospital-based use of natural bacteriophages is bound to have little impact on the environment in comparison with the emerging large scale use of bacteriophages in agriculture, cattle breeding and food industry. However, more fundamental as well as applied studies are required for optimizing and safely re-implementing bacteriophage therapy.

\section{References}

1. Levy SB, Marshall B (2004) Antibacterial resistance worldwide: causes, challenges and responses. Nat Med 10: S122-129.

2. Górski A, Miedzybrodzki R, Borysowski J, Weber-Dabrowska B, Lobocka M, et al. (2009) Bacteriophage therapy for the treatment of infections. Curr Opin Investig Drugs 10: 766-774.

3. ECDC (2009) The bacterial challenge: time to react. ECDC/EMEA Joint Technical Report.

4. Ackermann HW (2012) Who went into phage research? Bacteriophage 2: 5559.

5. Verbeken G, Pirnay JP, Lavigne R, Jennes S, De Vos D, et al. (2014) Call for a dedicated European legal framework for bacteriophage therapy. Arch Immunol Ther Exp (Warsz) 62: 117-129.

6. Wang CY, Jerng JS, Cheng KY, Lee LN, Yu CJ, et al. (2006) Pandrug-resistant
Pseudomonas aeruginosa among hospitalised patients: clinical features, risk factors and outcomes. Clinical Microbiology and Infection 12: 63-68.

7. Magiorakos AP, Srinivasan A, Carey RB, Carmeli Y, Falagas ME, et al. (2012) Multidrug-resistant, extensively drug-resistant and pandrug-resistant bacteria: an international expert proposal for interim standard definitions for acquired resistance. Clinical Microbiology and Infection 18: 268-281.

8. Infectious Diseases Society of America1 (2010) The 10 x '20 Initiative: pursuing a global commitment to develop 10 new antibacterial drugs by 2020. Clin Infect Dis 50: 1081-1083.

9. Bush K, Courvalin P, Dantas G, Davies J, Eisenstein B, et al. (2011) Tackling antibiotic resistance. Nat Rev Microbiol 9: 894-896.

10. GAIN (2012) Generating Antibiotics Incentives Now Act.

11. NDBBI (2012) New Drugs for Bad Bugs Initiative.

12. Brown ED (2013) Is the GAIN Act a turning point in new antibiotic discovery? Can J Microbiol 59: 153-156.

13. Huys I, Pirnay JP, Lavigne R, Jennes S, De Vos D, et al. (2013) Paving a regulatory pathway for phage therapy: Europe should muster the resources to financially, technically and legally support the introduction of phage therapy. EMBO reports 14: 951-954

14. Sulakvelidze A, Alavidze Z, Morris JG Jr (2001) Bacteriophage therapy. Antimicrob Agents Chemother 45: 649-659.

15. Thiel K (2004) Old dogma, new tricks--21st Century phage therapy. Nat Biotechnol 22: 31-36.

16. Brüssow H (2005) Phage therapy: the Escherichia coli experience. Microbiology 151: 2133-2140.

17. Kropinski AM (2006) Phage Therapy - Everything Old is New Again. Can J Infect Dis Med Microbiol 17: 297-306.

18. Fortuna W, Miedzybrodzki R, Weber-Dabrowska B, Górski A (2008) Bacteriophage therapy in children: facts and prospects. Med Sci Monit 14 RA126-132.

19. Kutateladze M, Adamia R (2008) Phage therapy experience at the Eliava Institute. Med Mal Infect 38: 426-430.

20. Mann NH (2008) The potential of phages to prevent MRSA infections. Res Microbiol 159: 400-405.

21. Chanishvili N, Sharp R (2009) Eliava Institute of Bacteriophage, Microbiology and Virology, Tbilisi, Georgia. A literature review of the practical application of bacteriophage research.

22. Górski A, Targonska M, Borysowski J, Weber-Dabrowska B (2009) The potential of phage therapy in bacterial infections of the eye. Ophthalmologica 223: $162-165$.

23. Rhoads DD, Wolcott RD, Kuskowski MA, Wolcott BM, Ward LS, et al. (2009) Bacteriophage therapy of venous leg ulcers in humans: results of a phase I safety trial. J Wound Care 18: 237-238, 240-3

24. Wright $A$, Hawkins $\mathrm{CH}$, Anggård $\mathrm{EE}$, Harper DR (2009) A controlled clinical tria of a therapeutic bacteriophage preparation in chronic otitis due to antibioticresistant Pseudomonas aeruginosa; a preliminary report of efficacy. Clin Otolaryngol 34: 349-357

25. Kutateladze M, Adamia R (2010) Bacteriophages as potential new therapeutics to replace or supplement antibiotics. Trends Biotechnol 28: 591-595.

26. Kutter E, De Vos D, Gvasalia G, Alavidze Z, Gogokhia L, et al. (2010) Phage therapy in clinical practice: treatment of human infections. Curr Pharm Biotechnol 11: 69-86.

27. Letkiewicz S, Miedzybrodzki R, Klak M, Jonczyk E, Weber-DÄBrowska B, et al. (2010) The perspectives of the application of phage therapy in chronic bacterial prostatitis. FEMS Immunol Med Microbiol 60: 99-112.

28. Abedon ST, Kuhl SJ, Blasdel BG, Kutter EM (2011) Phage treatment of human infections. Bacteriophage 1: 66-85.

29. Fernebro J (2011) Fighting bacterial infections-future treatment options. Drug Resist Updat 14: 125-139.

30. Harper DR, Enright MC (2011) Bacteriophages for the treatment of Pseudomonas aeruginosa infections. J Appl Microbiol 111: 1-7. 
Citation: Verbeken G, Pirnay JP, Lavigne R, Ceulemans C, De Vos D, et al. (2016) Viruses That Can Cure, When Antibiotics Fail.... J Microb Biochem Technol 8: 021-024. doi:10.4172/1948-5948.1000257

31. Khawaldeh A, Morales S, Dillo B, Alavidze Z, Ginn AN, et al. (2011) Bacteriophage therapy for refractory Pseudomonas aeruginosa urinary tract infection. Journal of Medical Microbiology 60: 1697-1700.

32. Miedzybrodzki R, Borysowski J, Weber-Dabrowska B, Fortuna W, Letkiewicz S, et al. (2012) Clinical aspects of phage therapy. Adv Virus Res 83: 73-121.

33. Borysowski J, Miedzybrodzki R, Górski A (2014) Phage therapy: current research and applications. Virulence 5: 13-23.

34. Wittebole X, De Roock S, Opal SM (2014) A historical overview of bacteriophage therapy as an alternative to antibiotics for the treatment of bacterial pathogens. Virulence 5: 226-235.

35. Abedon ST (2016) Phage therapy of pulmonary infections. Bacteriophage 5: e1020260.

36. Clark JR (2016) Bacteriophage therapy: history and future prospects. Future Virol 10: 449-461.

37. Kutter E, Kuhl SJ, Abedon S (2016) Re-establishing a place for phage therapy in western medicine. Future Medicine 10: 685-688.

38. Labrie SJ, Samson JE, Moineau S (2010) Bacteriophage resistance mechanisms. Nat Rev Microbiol 8: 317-327.

39. Sander JD, Joung JK (2014) CRISPR-Cas systems for editing, regulating and targeting genomes. Nat Biotechnol 32: 347-355.

40. Rath D, Amlinger L, Rath A, Lundgren M4 (2016) The CRISPR-Cas immune system: biology, mechanisms and applications. Biochimie 117: 119-128.

41. Lu TK, Koeris MS (2011) The next generation of bacteriophage therapy. Curr Opin Microbiol 14: 524-531.

42. Merabishvili M, De Vos D, Verbeken G, Kropinski A, Vandenheuvel D, et al (2012) Selection and characterization of a candidate therapeutic bacteriophage that lyses the Escherichia coli 0104:H4 strain from the 2011 outbreak in Germany. PLoS ONE 7: e52709.

43. DSMZ (2016) Leibniz-Institut DSMZ-Deutsche Sammlung von Mikroorganismen und Zellkulturen $\mathrm{GmbH} /$ Leibniz-Institute DSMZ - German Collection of Microorganisms and Cell Cultures, Braunschweig, Germany.

44. Buckling A, Rainey PB (2002) Antagonistic coevolution between a bacterium and a bacteriophage. Proc Biol Sci 269: 931-936.

45. Hendrix RW (2002) Bacteriophages: evolution of the majority. Theor Popul Biol 61: 471-480.

46. Faruque SM, Naser IB, Islam MJ, Faruque AS, Ghosh AN, et al. (2005) Seasonal epidemics of cholera inversely correlate with the prevalence of environmental cholera phages. Proc Natl Acad Sci U S A 102: 1702-1707.
47. Faruque SM, Islam MJ, Ahmad QS, Faruque AS, Sack DA, et al. (2005) Self-limiting nature of seasonal cholera epidemics: Role of host-mediated amplification of phage. Proc Natl Acad Sci U S A 102: 6119-6124.

48. Villarreal LP, Witzany G (2010) Viruses are essential agents within the roots and stem of the tree of life. J Theor Biol 262: 698-710.

49. De Vos D, Verbeken G, Rose T, Jennes S, Pirnay JP (2012) Bacteriophages for the treatment of severe infections: a "new" option for the future? EWMA Journal 12: 23-28.

50. Huys I, Vaneechoutte M, Verbeken G, Debarbieux L (2013) Key issues in phage therapy: a report of a dedicated workshop at the Viruses of Microbes II meeting. Res Microbiol 164: 806-810.

51. Pirnay JP, De Vos D, Verbeken G, Merabishvili M, Chanishvili N, et al. (2011) The phage therapy paradigm: prêt-à-porter or sur-mesure? Pharm Res 28 934-937.

52. Verbeken G, De Vos D, Vaneechoutte M, Merabishvili M, Zizi M, et al. (2007) European regulatory conundrum of phage therapy. Future Microbiol 2: 485491.

53. Pirnay JP, Verbeken G, Rose T, Jennes S, Zizi M, et al. (2012) Introducing yesterday's therapy in tomorrow's medicine. Future Virol 7: 379-390.

54. European Directive 2001/83/EC of the European Parliament and of the Council on the Community code relating to medicinal products for human use of 6 November 2001.

55. Bredin (2012) Avis hôpital militaire Reine Astrid - Keratinocytes (in French), Bredin-Prat lawyers office.

56. Verbeken G, Huys I, Pirnay JP, Jennes S, Chanishvili N, et al. (2014) Taking bacteriophage therapy seriously: a moral argument. BioMed Research International 2014: 8

57. Hall AR, De Vos D, Friman VP, Pirnay JP, Buckling A (2012) Effects of sequential and simultaneous applications of bacteriophages on populations of Pseudomonas aeruginosa in vitro and in wax moth larvae. Appl Environ Microbiol 78: 5646-5652.

58. Meaden S, Koskella B (2013) Exploring the risks of phage application in the environment. Front Microbiol 4: 358.

59. Schmerer M, Molineux IJ, Bull JJ (2014) Synergy as a rationale for phage therapy using phage cocktails. PeerJ 2: e590.

60. Friman VP, Soanes-Brown D, Sierocinski P, Molin S, Johansen HK, et al. (2016) Pre-adapting parasitic phages to a pathogen leads to increased pathogen clearance and lowered resistance evolution with Pseudomonas aeruginosa cystic fibrosis bacterial isolates. J Evol Biol 29: 188-198. 